\title{
果実ペクチン質の構成糖について
}

\author{
川端晶子, 澤 山茂 \\ 東京農業大学栄養学科
}

\section{Constituent Sugars of Pectic Substances from Fruits}

\author{
Akiko KAWABATA, Shigeru SAWAYAMA \\ Department of Nutrition, Tokyo University of Agriculture, Setagaya-ku, Tokyo
}

It is known that pectic substances are hetero polysaccharides constituted with several kinds of neutral sugars besides galacturonic acid.

For the purpose of obtaining basal information on the suitability for cooking and processing of pectic substances, we examined constituent sugars of pectic substances extracted from 20 kinds of fresh fruits and those of 4 kinds of commercial pectin.

The contents of anhydrogalacturonic acid in the pectic substances from fruits were $26.2 \%$ in banana pulp, $36.9 \%$ in banana peel, $38.8 \%$ in loquat and $39.8 \%$ in Japanese persimmon, while those from the other fruits were 50.4 to $74.7 \%$.

The fractionation of neutral sugars by liquid chromatography showed that the amounts of neutral sugars contained in each pectic substances were variable, but their kinds are almost similar. Arabinose or galactose was the largest in amount. The next largest ones were rhamnose and xylose. Mannose was very small in amount and the ribose amount was a trace. No constant result was obtained with glucose.

(Received May 30, 1975)

ペクチン質は, ガラクチュロン酸のほかに, アラビノ 一ス，ガラクトース，ラムノースなどの中性糖を含んだ 複合多糖類であることが知られている。

Barrette ら¹ はりんごペクチン質，Aspinall ら²)は レモンベクチン質の中に, アラビノース，ガラクトー ス, ラムノースなどの中性糖を認め, Abdel-Fattah ら゙) は玉荍の色のついた皮から分離したペクチン質に, フラビノース, キシロースのほか, クルコース, ガラク トース, ラムノースが含まれていることを報告し, Wold ら"は, けしの水溶性多糖類について, また Aspinall $5^{576)}$ や菊地 ${ }^{72 \sim 11)}$ は, 大豆多糖類について詳細に検討 しているが, 中性糖の含量はペクチン質によって相違 し,その種類はかなり多いるのあある。

ペクチン質の調理加工適性は, いままで主として，ガ ラクチニロン酸を主体として考えられてきたが，いま や，中性糖の成分についても考虑しなければならなくな ってきた。しかし，果実ペクチン質の構成糖についての 文献は少ない。著者らは,ペクチン溶液の粘性挙動や, ペクチン質のゲル化に扣よぼす要因を検討する基礎資料 を得る目的で, 新鮮果実から抽出したベクチン質および 市販ペクチン質の構成糖について検討したので報告す る。

テ 156 東京都世田谷区桜丘 1-1-1

\section{実 験 方 法}

\section{1. 実験材料}

実験材料としての果実は, 生果市場を経て入手した適 熟果, 柑きつ類では仏手柑 (fingered citron), グレーブ フルーツ (grape fruit), 金柑 (kumquat), 温州みか 几 (mandarine), 文旦 (shaddock), 柚子 (uzu) およ び夏みかんしぼり粕 (summer orange marc, 日本果実 工業株式会社提供), その他の果実類では, あんず (apricot), クんご (apple) の紅玉 (Kōgyoku), 祝 (lwai) およびミックスしぼり粕 (mixed marc, キッコー食品 工業株式会社提供), バナナ (banana, 当研究室で追熟 処理した追熟9日目の果肉および果皮 ${ }^{12)}$ ), 桜桃 (cherry), いちじく (fig), すぐり (gooseberry), 柿 (Japanese persimmon), びわ (loquat), プラム (plum), 赤すく り (red currant) および梅 (ume apricot)を用いた。

市販ペクチンは, アメリカ Sunkist Growers 製の Pectin National Formulary (N.F.), Slow set pectin (S.S.), Rapid set pectin (R.S.) および Low methoxyl pectin (L.M.)を用いた。標準䌅試料は、シュクロー ス, セロビオース, マルトース, ラクトース, リボー ス,ガラクトース, キシロースおよびクルコースは和光 純薬製, マンノース, アラビノースはメルク製, ラムノ 


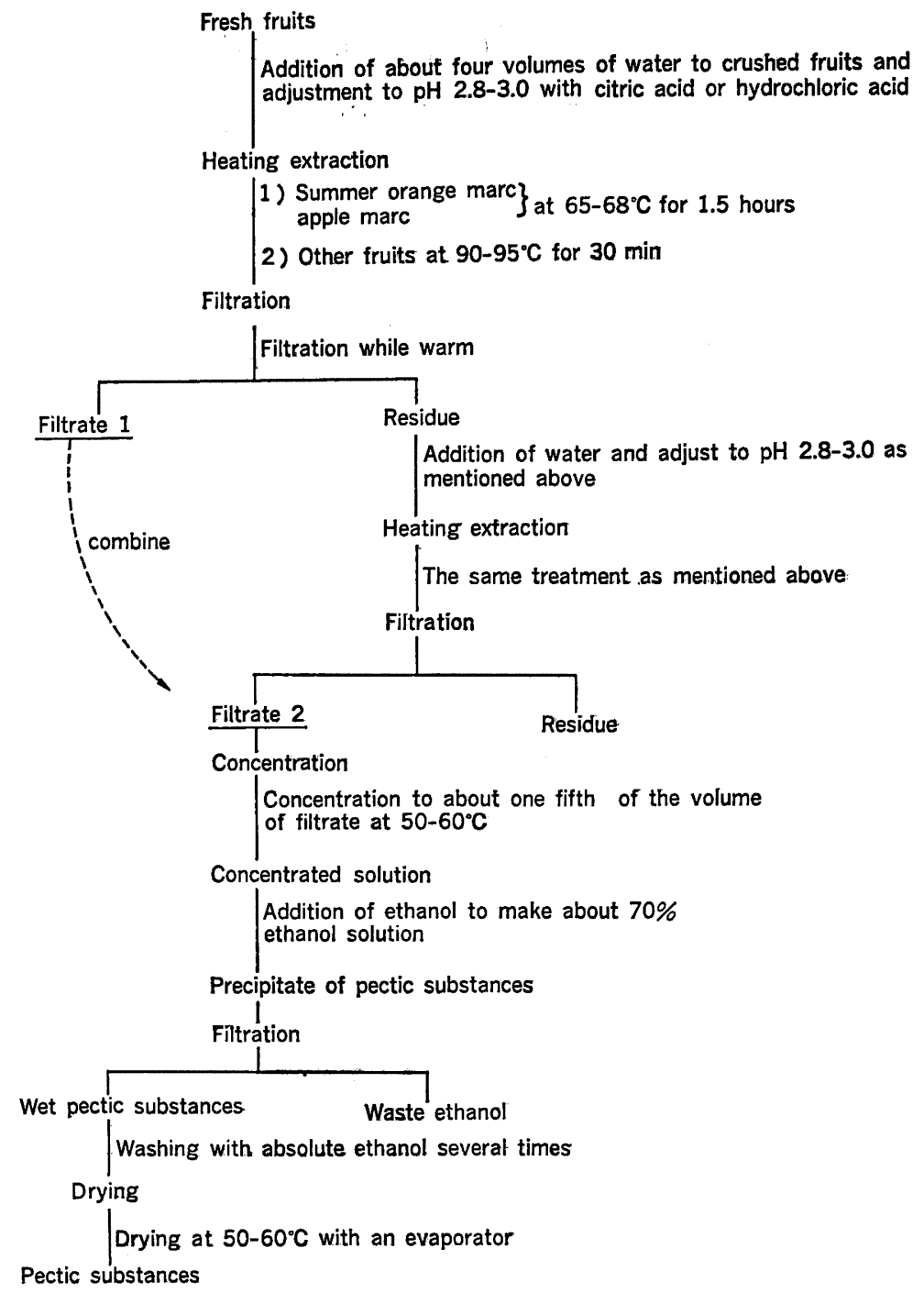

Fig. 1. Method for extracting pectic substances from fresh fruits.

\section{一スは武田化学薬品製を用いた。}

\section{2. 実験方法}

果実ペクチン質は, Fig. 1 に示すように, 原料果実 を破碎し約 4 倍量の水を加光，夏みかんおよびりんごし ぼり粕にはクェン酸を用い,その他の果実類には塩酸を 用いて $\mathrm{pH}$ 2.8 3.0 に調製し一定時間加熱抽出した。 温いらちに欂夜と残渣を分け，残渣に水を加えてるら一 度抽出をくり返し, 滤液を合わせて約 $1 / 5$ 量に減圧濃縮 し, エタノール沈殿法によってペクチン質を調製した。 市販ペクチンの精製は， 70\% エタノールを加えてミ キサーではげしく摫汼し，ヌッチェで滤過し，この操作 を 2 回くり返したのち，無水エタノールでさらに数回揗 汼洗浄をくり返してから乾燥試料とした。
1）ペクチン質の成分分析 水分, 窒素, 灰分は常法 により，ガラクチュロン酸は， $1 \%$ ベクチン溶液を $14,000 \times g$ で 10 分間遠心分離した上澄液に，等量の $0.1 \mathrm{~N}$ 水酸化ナトリウムを加光て室温で 40 分間ヶン化

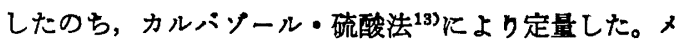
トキシル基は, 島津フルコキシル基定量装置による重量

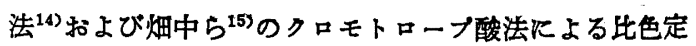
量法により測定した。

2）中性糖の定性と定量 上記 $1 \%$ ペクチン溶液の上 澄液に，等量の $2 \mathrm{~N}$ 硫酸を加えたすのをフンブル飞封 C, $100^{\circ} \mathrm{C}, 6$ 時間, 加水分解を行ない, Dowex $1 \times 2$

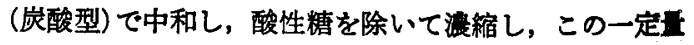
を東洋德紙 No. 51A とスポットし，酢酸エチル：飞リ 
シシ：水（10:4:3）ならびに, n-ブタノール：ピリジ ソ: 水 $(6: 4: 3)$ で展開して構成桾を確認したのち, 日 本電子株式会社製 JLC-6AH 型液体クロマトグラフを用 い，岡本ら ${ }^{16)}$ の方法に準じて定量した。すなわち，イオ ン交換カラムには, 陰イオン交換樹脂 LC-R-3（ホウ酸 型)をつめ, 展開液は, (1) $\mathrm{pH} 7.5,0.13 \mathrm{M} \mathrm{H}_{3} \mathrm{BO}_{3}$, (2) $\mathrm{pH} 9.0,0.25 \mathrm{M}-\mathrm{H}_{3} \mathrm{BO}_{3}$, (3) $\mathrm{pH} 9.6,0.35 \mathrm{M}-\mathrm{H}_{3} \mathrm{BO}_{3}$ 打 よび，(4) $0.5 \mathrm{M}-\mathrm{K}_{2} \mathrm{~B}_{4} \mathrm{O}_{7}$ を用い， $98 \%$ 硫酸 $1 l$ K $1.5 \mathrm{~g}$ のオルシンを溶解したるのを $0.63 \mathrm{~m} l / \mathrm{min}$ で発色反応 槽に送り， $425 \mathrm{~m} \mu$ の吸光度を測定した。各ピークの面 積は, 自動面積計により求め, 標準糖の面積との比から 陚料の糖の含有量を計算した。

標準煻試料は, クルコース $120 \mathrm{r} / \mathrm{ml}$, ガラクトース
$60 \mathrm{r} / \mathrm{ml}$, シュクロース, セロビオース, マンノース, アラビノースは $40 \mathrm{r} / \mathrm{m} l$, マルトース, ラクトースは $38 \mathrm{r} / \mathrm{m} l$, ラムノースは $36 \mathrm{r} / \mathrm{m} l$, キシロース, $35 \mathrm{rl}$ $\mathrm{m} l$, リボース $20 \mathrm{r} / \mathrm{m} l$ の割合に, $0.5 \mathrm{M} \mathrm{K}_{2} \mathrm{~B}_{4} \mathrm{O}_{7}$ に溶 解して用いた。ペクチン試料は，おのおの加水分解液を フェノール・硫酸法 ${ }^{17)}$ によって全糖量を求め, 適量にな るよらに $0.5 \mathrm{M} \mathrm{K}_{2} \mathrm{~B}_{4} \mathrm{O}_{7}$ に希积して用いた。

実験結果および考察

\section{1. ペクチン監の成分分析}

新鮮果実より分離調製した，ペクチン質の収量および 成分を Table 1 亿示す。

ペクチン質の収量は, 柑きつ類では一般に高く, 果汁

Table 1. Composition of fruits pectic substances.

(\%)

\begin{tabular}{|c|c|c|c|c|c|c|c|c|c|c|}
\hline & & & \multirow{3}{*}{ Yield } & \multirow{3}{*}{ Moisture } & \multirow{3}{*}{ Nitrogen } & \multirow{3}{*}{ Ash } & \multirow{3}{*}{ AGA* } & \multicolumn{3}{|c|}{ Methoxyl group } \\
\hline & & & & & & & & \multicolumn{2}{|c|}{$\begin{array}{l}\text { Gravimetric } \\
\text { method }\end{array}$} & \multirow[t]{2}{*}{$\begin{array}{l}\text { Colorimet- } \\
\text { ric method }\end{array}$} \\
\hline & & & & & & & & $\begin{array}{l}\text { Determina- } \\
\text { tion value }\end{array}$ & $\begin{array}{l}\text { AGA* } \\
\text { base }\end{array}$ & \\
\hline \multirow[t]{8}{*}{ 1) } & \multicolumn{10}{|l|}{ Citrus } \\
\hline & \multicolumn{2}{|c|}{ Fingered citron } & 3.21 & 12.9 & 0.31 & 1.32 & 57.1 & 6.52 & 11.4 & 6.44 \\
\hline & \multicolumn{2}{|c|}{ Grape fruit } & 0.81 & 11.3 & 0.77 & 2.43 & 51.4 & 7.10 & 13.8 & 7.07 \\
\hline & \multicolumn{2}{|c|}{ Kumquat } & 2.58 & 14.4 & 0.85 & 2.69 & 64.1 & 8.70 & 13.6 & 8.07 \\
\hline & \multicolumn{2}{|c|}{ Mandarine } & 2.37 & 13.3 & 0.61 & 3.54 & 46.7 & 6.14 & 13.1 & 6.21 \\
\hline & \multicolumn{2}{|c|}{ Summer orange marc } & 1.49 & 10.2 & 0.48 & 1.10 & 74.7 & 9.09 & 12.1 & 8.92 \\
\hline & \multicolumn{2}{|c|}{ Shaddock } & 1.79 & 13.6 & 0.49 & 3.90 & 59.0 & 7.95 & 13.5 & 7.80 \\
\hline & \multicolumn{2}{|c|}{ Uzu } & 2.11 & 12.6 & 0.85 & 1.12 & 56.6 & 7.20 & 12.7 & 7.12 \\
\hline \multirow[t]{15}{*}{ 2) } & \multicolumn{10}{|c|}{ Other fruits } \\
\hline & \multicolumn{2}{|c|}{ Apricot } & 0.88 & 12.9 & 1.91 & 4.26 & 55.1 & 7.09 & 12.9 & 6.77 \\
\hline & & (Kōgyoku & 0.76 & 10.6 & 1.36 & 4.22 & 50.4 & 5.93 & 11.8 & 5.22 \\
\hline & \multirow[t]{2}{*}{ Apple } & Iwai & 0.71 & 9.0 & 1.27 & 3.50 & 57.3 & 5.78 & 10.1 & 6.08 \\
\hline & & Mixed marc & 0.67 & 10.2 & 0.50 & 4.48 & 64.0 & 3.03 & 4.7 & 2.95 \\
\hline & \multirow{2}{*}{\multicolumn{2}{|c|}{ Banana $\left\{\begin{array}{l}\text { Peel } \\
\text { Pal }\end{array}\right.$}} & 1.50 & 10.4 & 2.14 & 4.20 & 26.2 & 2.80 & 10.7 & 2.48 \\
\hline & & & 0.78 & 10.8 & 1.43 & 5.20 & 36.9 & 4.58 & 12.4 & 4.47 \\
\hline & \multicolumn{2}{|l|}{ Cherry } & 0.70 & 10.4 & 1.89 & 2.76 & 54.2 & 5.00 & 9.2 & 4.85 \\
\hline & \multicolumn{2}{|l|}{ Fig } & 1.45 & 11.5 & 1.69 & 3.68 & 51.4 & 5.94 & 11.6 & 6.08 \\
\hline & \multicolumn{2}{|c|}{ Gooseberry } & 1.38 & 13.0 & 0.90 & 3.75 & 54.3 & 6.34 & 11.7 & 6.33 \\
\hline & \multicolumn{2}{|c|}{ Japanese persimmon } & 0.66 & 11.3 & 2.61 & 4.31 & 39.8 & 5.51 & 13.9 & 5.28 \\
\hline & \multicolumn{2}{|l|}{ Loquat } & 0.45 & 11.7 & 1.52 & 5.54 & 38.8 & 4.92 & 12.7 & 4.97 \\
\hline & \multicolumn{2}{|l|}{ Plum } & 0.86 & 13.0 & 1.88 & 3.36 & 52.8 & 6.63 & 12.6 & 6.60 \\
\hline & \multicolumn{2}{|c|}{ Red currant } & 0.85 & 13.0 & 0.90 & 2.75 & 56.3 & 7.37 & 13.1 & 6.45 \\
\hline & \multicolumn{2}{|c|}{ Ume apricot } & 0.64 & 12.7 & 1.68 & 3.45 & 55.4 & 5.21 & 9.4 & 5.02 \\
\hline
\end{tabular}


Table 2. Composition of commercial pectin.

\begin{tabular}{|c|c|c|c|c|c|c|c|c|}
\hline & & \multirow{3}{*}{ Moisture } & \multirow{3}{*}{ Nitrogen } & \multirow{3}{*}{ Ash } & \multirow{3}{*}{ AGA* } & \multicolumn{3}{|c|}{ Methoxyl group } \\
\hline & & & & & & \multicolumn{2}{|c|}{$\begin{array}{l}\text { Gravimetric } \\
\text { method }\end{array}$} & \multirow[t]{2}{*}{$\begin{array}{l}\text { Colorimetric } \\
\text { method }\end{array}$} \\
\hline & & & & & & $\begin{array}{l}\text { Determina- } \\
\text { tion value }\end{array}$ & $\begin{array}{l}\text { AGA* } \\
\text { base }\end{array}$ & \\
\hline \multirow[t]{5}{*}{ 1) } & Crude pectin & & & & & & & \\
\hline & N. F. & 10.22 & 0.81 & 3.81 & 71.7 & 8.67 & 12.09 & 8.07 \\
\hline & S. S. & 10.07 & 0.57 & 1.06 & 60.9 & 6.06 & 9.95 & 5.99 \\
\hline & R. S. & 11.25 & 0.60 & 1.80 & 61.3 & 7.16 & 11.68 & 7.09 \\
\hline & L. M. & 10.24 & 1.25 & 2.98 & 53.5 & 3.36 & 6.28 & 3.40 \\
\hline \multirow[t]{5}{*}{ 2) } & Purified pectin & & & & & & & \\
\hline & N. F. & 12.20 & 0.59 & 3.17 & 74.1 & 9.60 & 12.75 & 9.19 \\
\hline & S. S. & 12.28 & 0.53 & 0.90 & 73.2 & 8.67 & 11.84 & 8.15 \\
\hline & R. S. & 12.22 & 0.65 & 1.92 & 74.6 & 8.77 & 11.75 & 8.28 \\
\hline & L. M. & 12.52 & 0.91 & 3.09 & 70.7 & 4.32 & 6.11 & 4.25 \\
\hline
\end{tabular}

N.F. = pectin national formulary, S.S.=slow set pectin, R.S.= rapid set pectin,

L.M.=low methoxyl pectin, AGA*=anhydrogalacturonic acid.

の多いクレープフルーツは $0.81 \%$ であるが，ほとんど が果皮である仏手柑では $3 \%$ を上わっている。その他 の果実類では， $0.45 \sim 1.50 \%$ であった。無水ガラクチ ニロン酸含量は, $50 \%$ 前後のものが多いが, バナナペ クチン質の含量は低く, 果肉は $26.2 \%$, 果皮は $36.9 \%$ で, 夏みかんしぼり粕は最も高く $74.7 \%$ であった。重 量法および比色定量法によるメトキシル基含量は, 比色 定量法のほうが総体的にやや低い值にでる傾向にある が，ほぼ近似値を得ている。重量法による定量值では 2.80 9.09\% であるが，無水ガラクチュロン酸ベース に換算すれば,りんごしぼり粕ペクチン質を除き 9.21〜 $13.84 \%$ で，高メトキシルペクチンといえる。りんごし
ぼり粕ペクチン質が，無水ガラクチュロン酸ベースで $4.73 \%$ といら低い值を示しているが，これは調製まで の間に脱メチル化が行なわれたのか，もともと低メトキ シルなのか不明である。

Table 2 に, 市販ペクチンとその精製ペクチンの分析 值を示す。いずれも精製したものの, 無水ガラクチュロ ン酸およびメトキシル基含量がやや高くなっている。

これは, 精製処理によって, エタノール可溶性成分が 溶出した結果によるものと考えられる。

2. 液体クロマトグラフィーによる中性桔の分別定量

Fig. 2 K，標準桾類のクロマトグラムを示す。岡本 $ら^{16)}$ が報告しているように，本条件による液体クロマト

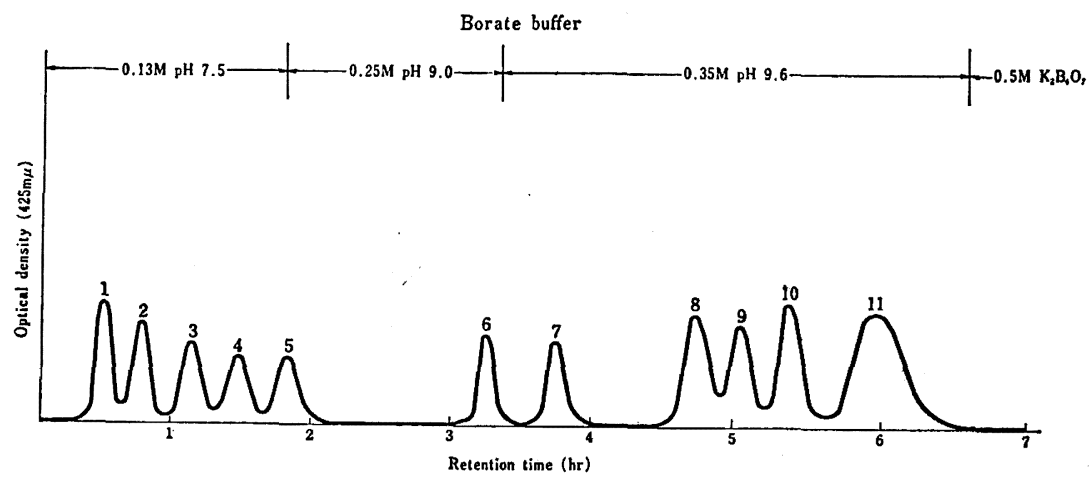

Fig. 2. Liquid chromatographic pattern of standard sugars.

1. sucrose $40 \mathrm{r} / \mathrm{ml}$, 2. cellobiose $40 \mathrm{r} / \mathrm{ml}$, 3. maltose $38 \mathrm{r} / \mathrm{ml}$, 4. lactose $38 \mathrm{r} / \mathrm{ml}$,

5. rhamnose $36 \mathrm{r} / \mathrm{ml}$, 6. ribose $20 \mathrm{r} / \mathrm{ml}$, 7. mannose $40 \mathrm{r} / \mathrm{ml}$, 8. arabinose $40 \mathrm{r} / \mathrm{ml}$,

9. galactose $60 \mathrm{r} / \mathrm{ml}$, 10. xylose $35 \mathrm{r} / \mathrm{ml}$, 11. glucose $20 \mathrm{r} / \mathrm{ml}$. 
Grape fruit

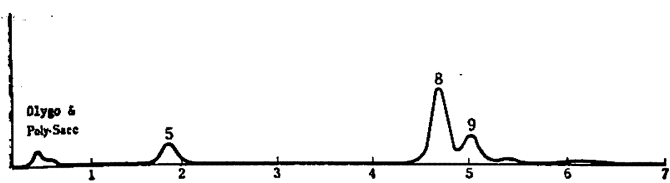

Summer orange marc
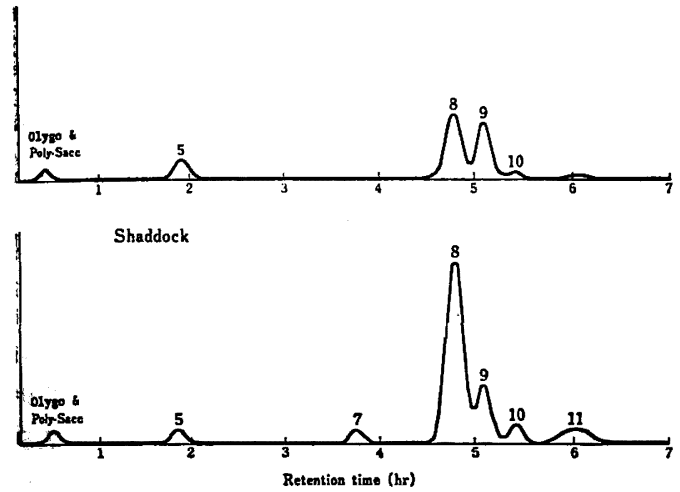

Fig. 3. Liquid chromatographic patterns of citrus pectic substances.

グラフィーでは, アラビノースとフラクトースのピーク 蛛先端で分離するが，半値幅以上の分離は不可能である ことと，本実験に用いたペクチン質のペーパークロマト グラフィーによる予備実験の結果, フラクトースは確認 されなかったので，フラクトースは標準糖液から除い た。

Fig. 3 には，相きつ類中，グレープフルーッ，夏み
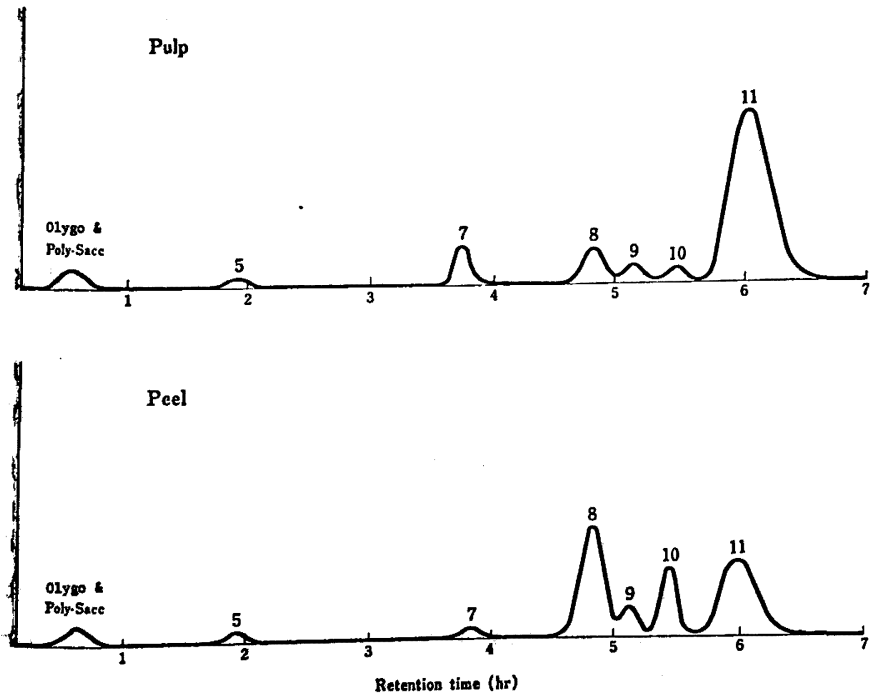

Fig. 5. Liquid chromatographic patterns of banana pectic substances.

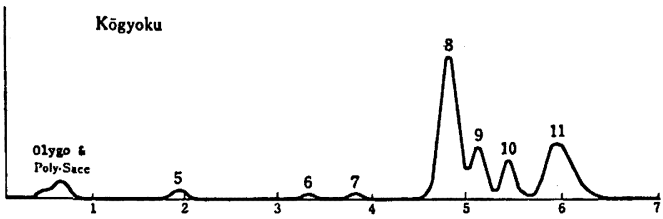

Iwai
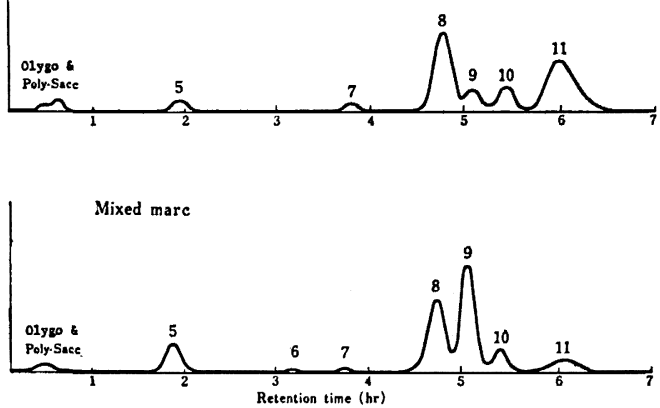

Fig. 4. Liquid chromatographic patterns of apple pectic substances.

かんしぼり粕，文旦ペクチン質，Fig. 4 には，りんごぺ クチン質のクロマトグラムを示す。柑きつ類ペクチン質 では，アラビノースおよびガラクトースが目立って大き く,つづいてラムノースのピークが見られた。りんごペ クチン質では, アラビノース, ガラクトースのほかにグ ルコース，キシロース拈よびラムノースのピークも見ら れた。

Fig. 5 には, バナナ果肉扰よび果皮ぺ クチン質のクロマトグラムを示す。果肉 ペクチン質ではグルコースのピークがと くに目立っている。バナナ果肉は, 追熟 中にでんぷん含量が減少するが，追熟 9 日目であ若干残っているので12)，グルコ 一スのピークは,でんぷんに由来するる のと考えられる。

いずれのクロマトグラムにも見られる シュクロースの展開位置付近の小さなピ 一クは，少糖類や多糖類の未分解成分と 考えられるが，これらについて本実験で は追求しなかった。

Table 3 K, 各果実ペクチン質の中性 糖分析定量値をまとめて示す。

総体的に，フラビノース，ガラクトー スの含量が高く, つついてラムノース, キシロースがほとんどのペクチン質に含 まれている。ダルコース含量には，極端 
Table 3. Neutral sugar of fruits pectic substances.

(\%)

\begin{tabular}{|c|c|c|c|c|c|c|c|c|c|c|}
\hline & & & Rhamnose & Ribose & Mannose & $\begin{array}{l}\text { Arabi- } \\
\text { nose }\end{array}$ & Galactose & Xylose & Glucose & Total \\
\hline \multirow[t]{8}{*}{ 1) } & \multicolumn{10}{|l|}{ Citrus } \\
\hline & \multicolumn{2}{|c|}{ Fingered citron } & 0.5 & trace & 0.2 & 4.9 & 5.2 & 0.2 & 0.7 & 11.7 \\
\hline & \multicolumn{2}{|c|}{ Grape fruit } & 0.5 & & & 2.4 & 1.2 & & & 4.1 \\
\hline & \multicolumn{2}{|c|}{ Kumquat } & 0.5 & trace & 0.2 & 4.1 & 4.7 & 0.4 & 1.0 & 10.9 \\
\hline & \multicolumn{2}{|c|}{ Mandarine } & 1.1 & trace & trace & 7.8 & 4.8 & 0.3 & 2.4 & 16.4 \\
\hline & \multicolumn{2}{|c|}{ Summer orange marc } & 0.5 & & & 1.6 & 1.9 & trace & & 4.0 \\
\hline & \multicolumn{2}{|c|}{ Shaddock } & 0.4 & & 2.5 & 5.5 & 1.6 & 0.2 & 0.4 & 10.6 \\
\hline & \multicolumn{2}{|c|}{ Uzu } & 0.2 & & trace & 1.4 & 2.2 & 0.2 & 7.4 & 11.4 \\
\hline \multirow[t]{15}{*}{ 2) } & \multicolumn{10}{|c|}{ Other fruits } \\
\hline & \multicolumn{2}{|c|}{ Apricot } & 0.6 & & trace & 2.3 & 1.3 & trace & trace & 4.2 \\
\hline & & Kōgyoku & 0.2 & trace & trace & 6.8 & 1.5 & 0.5 & 2.4 & 11.4 \\
\hline & \multirow[t]{2}{*}{ Apple } & $\{$ Iwai & 0.3 & & 0.1 & 2.6 & 0.7 & 0.3 & 1.9 & 5.9 \\
\hline & & Mixed marc & 0.7 & trace & trace & 3.1 & 3.0 & 0.4 & 0.3 & 7.5 \\
\hline & \multirow{2}{*}{\multicolumn{2}{|c|}{ Banana $\left\{\begin{array}{l}\text { Pulp } \\
\text { Peel }\end{array}\right.$}} & trace & & 0.7 & 0.6 & 0.5 & 0.1 & 7.3 & 9.2 \\
\hline & & & trace & & trace & 4.5 & 0.9 & 0.8 & 2.9 & 9.1 \\
\hline & \multicolumn{2}{|l|}{ Cherry } & 0.5 & & 0.3 & 3.2 & 2.2 & trace & 1.9 & 8.1 \\
\hline & \multicolumn{2}{|c|}{ Fig } & trace & & trace & 2.1 & 0.7 & trace & 1.2 & 4.0 \\
\hline & \multicolumn{2}{|c|}{ Gooseberry } & 0.9 & trace & 0.2 & 4.4 & 5.9 & 0.2 & 1.1 & 12.7 \\
\hline & \multicolumn{2}{|c|}{ Japanese persimmon } & 0.4 & 0.1 & trace & 3.3 & 3.1 & 1.1 & 3.7 & 11.7 \\
\hline & \multicolumn{2}{|c|}{ Loquat } & 0.2 & & 0.2 & 10.1 & 1.4 & 0.7 & 0.4 & 13.0 \\
\hline & \multicolumn{2}{|c|}{ Plum } & 0.2 & 0.1 & 0.2 & 3.4 & 6.5 & 0.2 & 0.9 & 11.5 \\
\hline & \multicolumn{2}{|c|}{ Red currant } & 0.2 & & 0.1 & 6.2 & 1.5 & 0.4 & 0.3 & 8.7 \\
\hline & \multicolumn{2}{|c|}{ Ume apricot } & 0.5 & trace & 0.4 & 3.6 & 3.7 & 0.5 & 0.6 & 9.3 \\
\hline
\end{tabular}

そ多いものと少ないものが見られ，マンノースはごく少 量か痕跡程度であった。含量の高いアラビノースとガラ クトースの比に，一定の傾向は見られなかった。 Barrette ら $^{1)}$ のんごペクチン質中のアラビノースとガラ クトースの比は $7: 1$ であるが, 紅玉, 祝のペクチン質 ではほぼ 6:1 の比を示している。しかし,りんごしぽ り粕ペクチン質では逆に，ガラクトースの割合が大きく なっている。また，果実ぺクチン質の中性糖の総含量に る一定の傾向は見られず，無水ガラクチュロン酸と中性 糖の含量にる，相関はなさそらである。

Fig. 6 飞, 市販ペクチン, R.S. および L.M. ペクチ ンのクロマトグラムを示す。

いずれにも，ガラクトース，フラビノース，ラムノー ス, キシロースのピークが見られるが，とくに未処理ペ クチンに, クルコースの大きなピークが見られるのに対 し, 精製ペクチンでは, グルコースのピークがまったく 認められなかった。このことについて，精製時の廃エタ ノール中の糖を, ペーパークロマトクラフィーによって
定性した結果, グルュースのみのスポットが認められた ので, このピークは, クルコースそのものおよびェタノ 一ル中に溶出し，加水分解によってクルコースを生成す る低分子の成分の混在を意味するものである。

Table 4 に, 市販ペクチンの中性糖の分析定量值をま とめて示す。

いずれのペクチンも，ガラクトースの含量が最む高 く,つついてアラビノース, ラムノースが含まれ，キシ ロースは僅少であった。ペクチン N.F.は，精製処理を しても，中性糖の成分はほぼ一定であった。未処理の R.S. 抽よ゙ S.S. ペクチンでは 12 13\%, L.M. ペク チンでは，16\% のグルコースが定量されだ。

果実ペクチン質では, ガラクトースとフラビノースの 含量比に一定の傾向は見られなかったが，市販へクチン では，いずれもガラクトースの含量が大で，フラビノー ス, ラムノースがそれにつづいてい。

現在, Pilnik ら ${ }^{187}$ 《よると。中性糖は必ずべタン 質に確認され，ラムノースはガラクチニロン酸の主鎖中 
Table 4. Neutral sugar of commercial pectin.

\begin{tabular}{|c|c|c|c|c|c|c|c|c|c|}
\hline & & Rhamnose & Ribose & Mannose & $\begin{array}{l}\text { Arabi- } \\
\text { nose }\end{array}$ & Galactose & Xylose & Glucose & Total \\
\hline \multirow[t]{5}{*}{ 1) } & Crude pectin & & & & & & & & \\
\hline & N. F. & 0.4 & & & 1.2 & 2.6 & trace & & 4.2 \\
\hline & S. S. & 0.2 & trace & trace & 0.5 & 4.2 & 0.1 & 16.8 & 21.8 \\
\hline & R. S. & 0.8 & trace & trace & 1.0 & 4.1 & 0.1 & 16.0 & 22.0 \\
\hline & L. M. & 0.4 & & & 0.6 & 1.5 & trace & 19.6 & 22.1 \\
\hline \multirow[t]{5}{*}{ 2) } & Purified pectin & & & & & & & & \\
\hline & N. F. & 0.6 & & & 1.2 & 3.0 & trace & & 4.8 \\
\hline & S. S. & 0.6 & & & 0.7 & 4.8 & 0.1 & & 6.2 \\
\hline & R. S. & 0.3 & & & 0.9 & 4.7 & trace & & 5.9 \\
\hline & L. M. & 0.4 & & & 0.6 & 1.7 & trace & & 2.7 \\
\hline
\end{tabular}

N.F.=pectin national formulary, S.S.=slow set pectin, R.S.=rapid set pectin, L.M. $=$ low methoxyl pectin, $\mathrm{AGA}^{*}=$ anhydrogalacturonic acid.
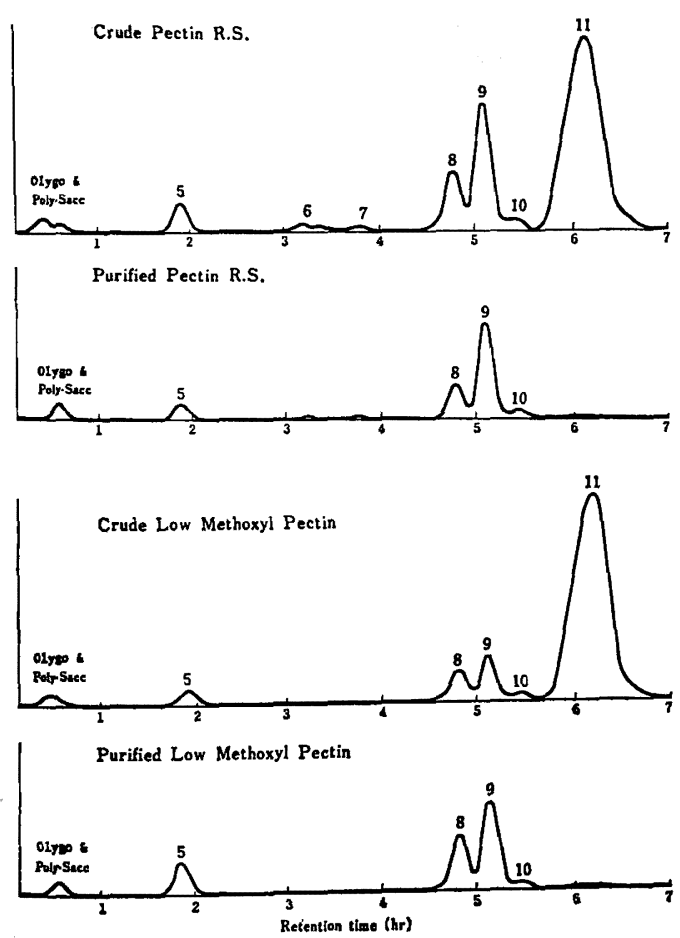

Fig. 6. Liquid chromatographic patterns of commercial pectin.

К介在するが，フラビノース，ガラクトースおよびキシ ロースは，㑡鎖に共有結合しているすのと混在するすの があると考えられているが，本実験ではこれらの判定は つかない。

今後, どのような形で存在している中性糖が, ペクチ
ン質の粘性挙動やゲル化に影響をおよぼすかを検討した いと考えている。

\section{要約}

1）新鮮果実より分離調製したペクチン質の収量は, 相きつ類では $0.80 \sim 3.21 \%$ で，その他の果実類では 0.45 1.50\% であった。これらのペクチン質の成分を 分析定量した結果, 無水ガラクチュロン酸含量は $50 \%$ 前後のものが多いが，バナナペクチン質の含量は低く， 果肉 $26.2 \%$, 果皮 $36.9 \%$ で夏みかんしぼり粕ペクチ ン質は最も高く, $74.7 \%$ であった。

重量法によるメトキシル基の定量値は，2.80 9.09\% であるが, 無水ガラクチュロン酸べースに換算すると, りんごしぼり粕ペクチン質を除き，9.21 13.84\% とな り，高メトキシルペクチンといえる。

市販ペクチンについて，末処理および精製したものに ついて成分を分析定量した結果, 精製したものの無水が ラクチュロン酸およびメトキシル基含量がやや高くなっ ている。

2）液体クロマトグラフィーによる中性糖の分別定量 の結果, 果実ベクチン質に含まれる中性糖の量は異なる が，種類はほぼ一定していることが認められた。

総体的に, アラビノース, ガラクトースの含量が高 く,つついてラムノース, キシロースがほとんどのペク チン質に含まれ, タルルースは, 極端に多いるのと少な いものがある。

含量の高いアラビノースとガラクトースの比には一定 の㑯向は見られず，中性糖の総含量にる一定の傾向はな く,また無水ガラクチュロン酸と中性糖の含量にも相関 
はなさそらである。

本稿を終えるにあたり, 終始, ご留切なるご指導とご 校閲を賜りました本学教授小原哲二郎博士に，深甚の謝 意を表します。また，中性糖の液体クロマトグラフィー について，ご指導とご便宜を怙はかりくださいましたキ ッコーマン醬油株式会社中央研究所所長横塚保博士なら びに石井茂孝博士, 神戸千幸氏に深く感謝し, あわせて ペクチン質の分離調製にご便宜をおはかりくださいまし た帝国葴器製薬株式会社澤井政信氏に感謝いたします。 本研究は, 昭和49年度文部省科学研究費の助成を受け て行なったものであり，また本報告の要旨は，昭和50年 5 月24日, 第29回日本栄養・食糧学会総会に执いて発表 した。

\section{文献}

1) Barrette, A.J. and Northcote, D.H. : Biochem. J., 94, 617 (1965)

2) Aspinall, G.O., Craig, J.W.T. and Whyte, J.Z. : Carbohydrate Res., 7, 442 (1968)

3) Abdel-Fattah, A.F. and Edress, M. : J. Sci. Food Agr., 22, 298 (1971)

4) Wold, J.K., Smestad, B., Winsnes, R. and Resser, W. : Acta Chem. Scand., 24, 1262
(1970)

5) Aspinall, G.O., Begbie, R., Hamilton, A. and Whyte, J.N.C. : J. Chem. Soc., 1967, 1065

6) Aspinall, G.O., Cottrell, I.W., Egan, V., Sylvia, Morrison, I.M. and Whyte, J.N.C. : J. Chem. Soc., 1967, 1071

7）菊地忠昭, 石井茂孝, 福島男児, 横塚 保: 農化, 45, 228 (1971)

8）菊地忠昭, 石井茂孝, 福島男児, 横塚 保: 農化, 45, 235 (1971)

9) Kikuchi, T. and Yokotsuka, T. : Agr. Biol. Chem., 36, 544 (1972)

10) Kikuchi, T. and Yokotsuka, T. : Agr. Biol. Chem., 37, 973 (1973)

11) Kikuchi, T. and Yokotsuka, T. : Agr. Biol. Chem., 37, 2473 (1973)

12）川端晶子, 澤山 茂 : 栄養之食糧, 27, 21 (1974)

13) Bitter, T. and Muir, H.M. : Anal. Biochem., 4, 330 (1962)

14）日本分析化学有機微量分析研究琶談会編：有機微 量定量分析, 439 (1967)，南江堂

15）畑中千歳, 小沢潤二郎：農化，40，421 (1966)

16) 岡本 武, 竹上伊津子: 調味科学, 18,342(1971)

17) Dubois, M., Gilles, K.A., Hamilton, J.K., Rebers, P.A. and Smith, F. : Anal. Chem., 28, 350 (1956)

18) Pilnik, W. and Voragen, A.G.J.: The Biochemistry of Fruits and their Products, Vol. 1, 53 (1970), Academic Press

（昭和50年 5 月 30 日受理） 